
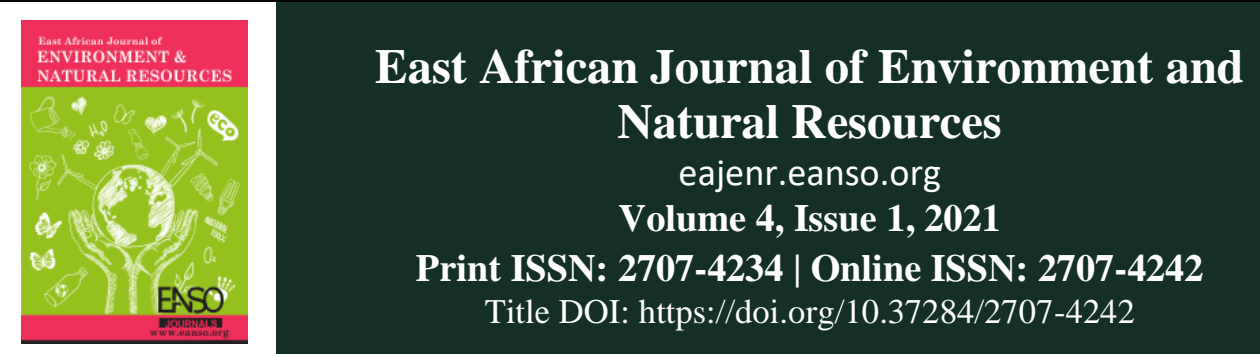

Original Article

\title{
Settlement Schemes and their Implication on Eastern Mau Water Catchment, Kenya.
}

\author{
Fredah Cherotich ${ }^{1} \&$ Sammy Letema ${ }^{1}$ \\ ${ }^{1}$ Kenyatta University, P. O. Box 43844-00100 Nairobi, Kenya. \\ *Correspondence ORCID ID: https://orcid.org/0000-0003-1013-235X; email: fredahm25@ gmail.com.
}

Article DOI: https://doi.org/10.37284/eajenr.4.1.484

\section{Date Published: ABSTRACT}

26 November 2021

Keywords:

Settlement Schemes,

Water Catchment,

Land Use/Cover, River Flows,

Eastern Mau Forest Reserve.
Settlement schemes are aimed at settling landless people and those displaced by disasters to support socio-economic and environmental development of a country. Eastern Mau Forest Reserve is an important water catchment that has settlement schemes established, which has led to encroachments and degradation of the catchment. This paper, therefore, assesses the implications of human settlements on Eastern Mau water catchment by examining the trends in land use/cover change and river flows for four decades. Primary data was collected from key informant interviews based on purposive sampling whereas secondary data was derived from Landsat satellite images over a 10-year period and analysed using Maximum Likelihood Function from ArcGIS. Data on river flows from River Njoro was obtained from Water Resources Authority Office in Nakuru. Rainfall and temperature data were obtained from Kenya Meteorological Station in Nakuru. Time series analysis is used to understand the trend in river flows over time while Pearson correlation is used to determine relationship between farmlands and river flows. The results indicate a sharp decline in forest cover by $42.7 \%$ and an increase in farmlands by $41 \%$. Dense vegetation and farmlands have an inverse relationship as an increase in farmlands lead to a decrease in forest cover. People have settled beyond the established settlement schemes boundaries leading to encroachment and drying up of some rivers. There is also an increase in rainfall and river flows over the years, with monthly river flows increasing in peak flows and declining during low seasons. There is a positive correlation between farmlands and river flows between 1989 and 2020. There is need for regeneration of encroached areas and defining boundary of Eastern Mau to allow initiatives and interventions that help with sustainable management of the catchment area.

39 | This work is licensed under a Creative Commons Attribution 4.0 International License. 
East African Journal of Environment and Natural Resources, Volume 4, Issue 1, 2021

Article DOI: https://doi.org/10.37284/eajenr.4.1.484

APA CITATION

Cherotich, F. \& Letema, S. (2021). Settlement Schemes and their Implication on Eastern Mau Water Catchment, Kenya. East African Journal of Environment and Natural Resources, 4(1), 39-51. https://doi.org/10.37284/eajenr .4.1.484

\section{CHICAGO CITATION}

Cherotich, Fredah \& Sammy Letema. 2021. "Settlement Schemes and their Implication on Eastern Mau Water Catchment, Kenya”. East African Journal of Environment and Natural Resources 4 (1), 39-51. https://doi.org/10.37284/eajenr.4.1.484.

\section{HARVARD CITATION}

Cherotich, F. Letema, S. (2021) "Settlement Schemes and their Implication on Eastern Mau Water Catchment, Kenya", East African Journal of Environment and Natural Resources, 4(1), pp. 39-51. doi: 10.37284/eajenr.4.1.484.

\section{IEEE CITATION}

F. Cherotich S. Letema, "Settlement Schemes and their Implication on Eastern Mau Water Catchment, Kenya", EAJENR, vol. 4, no. 1, pp. 39-51, Nov 2021.

\section{MLA CITATION}

Cherotich, Fredah \& Sammy Letema. "Settlement Schemes and their Implication on Eastern Mau Water Catchment, Kenya". East African Journal of Environment and Natural Resources, Vol. 4, no. 1, Nov 2021, pp. 39-51, doi:10.37284/eajenr.4.1.484.

\section{INTRODUCTION}

Forests are important ecological systems as they provide ecosystems functions and services (Prăvălie, 2018). Despite their importance, the global forest area has decreased alarmingly over the last few decades with vast effects felt across various regions (Alamgir et al., 2020). This has resulted in efforts towards management of forest land to improve continuous flow of forests products and services with minimal effects on physical and social environment while enhancing sustainable development (Gills \& Morgan, 2020). These efforts include development of regulations, agreements, institutions and initiatives at international and national level aimed at management of forests (Jorge \& Julio, 2012).

The increase in population coupled with the need for more land for agricultural activities has led to people settling in forested area. In several regions across the world, there is a conflict between forests and agriculture (Yang et al., 2018). Despite the presence of regulations meant to protect forests, humans have continuously settled and destroyed forests (Lopez \& Jason, 2013). Settlements schemes have also been established in forested areas by authorities in a bid to settle landless people, reduce population in highly populated area, increase food production and settle people displaced by different disasters (Sauer, 2018). There is rampant encroachment of the forested areas which further leads to destruction of forests.
Settlement schemes in forested areas lead to destruction of catchments and disrupt forest and catchment management efforts (Sauer, 2018). As people clear forests to pave way for settlements, deforestation and land degradation sets in (Gills \& Morgan, 2020). This further leads to soil erosion, destruction of animal and plant habitats and depletion of water resources. Land use, land cover changes further leads to sedimentation which alter the river flows (Masuma \& Adullah, 2020). Settlement programs hinder efforts aimed at sustainable use of natural resources and planning of catchments.

The last three decades have seen the Mau Forest Complex undergo changes in land uses as a result of population pressure, the need for land to settle and carry out agricultural activities (KWTA, 2017). The establishment of settlement schemes in a forested area and further encroachment has led to deforestation of Mau (Shazia, 2019). The result of settling in Eastern Mau Forest Reserve is degradation of land and destruction of wetlands which may impact flow of rivers during the dry seasons (Kibuba \& Jenkins, 2005). The land administration systems in Kenya have allowed previous regimes to establish settlement schemes in forest areas (Olang \& Kundu, 2011).

People who were allocated land when settlement schemes were established have over time engaged in agricultural activities resulting in land use land cover changes (Anthony, 2018). The creation of settlement schemes in the forest has led to

40 | This work is licensed under a Creative Commons Attribution 4.0 International License. 
destruction of wetlands consequently leading to disruption of the river flow regime and drying up of some water sources (Guzha \& Rufino, 2018). Landuse changes increase run-off and sediment deposition in rivers as more people engage in agricultural activities. The relationship between settlements in forested areas and river flows and water catchments have not been fully analysed, which is the focus of study.

The study aimed to examine land use and land cover changes in Eastern Mau Forest Reserve from 1979 to 2020, examine settlement schemes and boundaries in Eastern Mau Forest Reserve between 1979 and 2020 and assess the impact of settlement schemes on river flows in Eastern Mau Forest Reserve from 1979 to 2020.

\section{METHODOLOGY}

The paper is based on Eastern Mau Forest Reserve located in Nakuru County in Kenya situated in the longitude $35^{\circ} 46^{\prime} 30^{\prime \prime} \mathrm{E}, 36^{\circ} 7^{\prime} 30^{\prime \prime} \mathrm{E}$ and latitude $0^{\circ} 20^{\prime} 0^{\prime \prime} \mathrm{S}$ and $0^{\circ} 40^{\prime} 0^{\prime \prime} \mathrm{S}$ (Figure 1). It makes up one of the two largest blocks in the Mau Forest Complex.

\section{Figure 1: Eastern Mau Forest Reserve as part of large Mau Forest Complex}

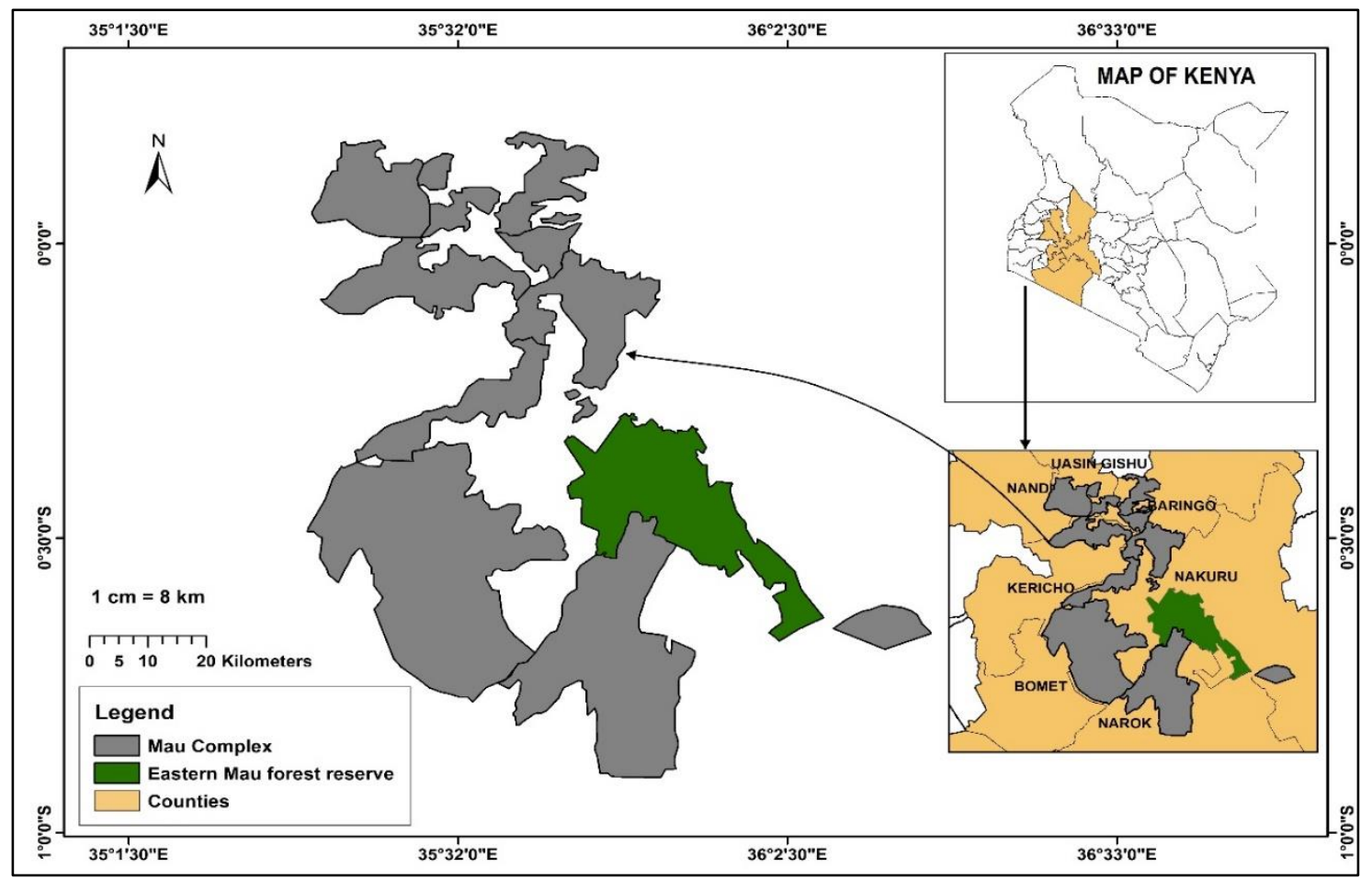

Primary data was obtained from key informant interviews administered to officials from Kenya Forest Service, Water Resources Authority, National Environmental Management Authority, Kenya Meteorological Department, and Nakuru County Department of Physical Planning and Ministry of Environment. Secondary data was obtained from maps of settlement schemes, boundaries from Survey of Kenya and documents. Landsat satellite data was obtained from Earth explorer over an interval of 10 years from 19792020 and analysed based on supervised classification method using the Maximum
Likelihood Function from ArcGIS. Rainfall data was obtained from Kenya Meteorological Department for 1979-2020. The data on river flows for river Njoro was obtained from $2 \mathrm{FC} 11$ gauging station from January 1979 to December 2020. The mean annual and monthly river flows are used to determine the changes in river flows over the years. The mean annual river flows are tabulated alongside the mean annual rainfall obtained from Molo Forest Station. The mean monthly river flows for each year are used to further understand how the flows in River Njoro vary per month. An interval of 10 years is used to determine changes that have taken place 
over time during the rainy seasons. Time series analysis is used to understand the trend in river flows over time whereas Pearson correlation is used to determine relationship between farmlands and river flows. Content analysis is used to analyse data from key informant interviews and reports.

\section{RESULTS AND DISCUSSION}

\section{Land Use and Land Cover Changes in Eastern Mau Forest Reserve}

Figure 2 and 3 shows the land cover changes in Eastern Mau Forest Reserve from 1979 to 2020. In 1979, the forest was covered mostly with dense vegetation and woodlands, with a few spots of farmlands spread across the forest reserve while in 2020, farmlands are more dominant. Between 1989 and 2009, there is a decline in dense vegetation and increase in farmlands. In contrast, there is a slight increase in dense vegetation spread out across the areas that had been occupied by farmlands in 2020 . In Figure 2 and 3, the forested areas which have dense vegetation have been decreasing from 1979 to 2009 gradually with a slight increase in 2020 . Dense vegetation decreased by $42.7 \%$ from $96896 \mathrm{Ha}$ to
$30572 \mathrm{Ha}$ in the period 1979 to 2020. During the same period, farmlands increased from 7309 Ha to $68547 \mathrm{Ha}$ which represents $41 \%$ increase. The greatest decline in forest vegetation cover and increase in farm lands is between 1979 and 2009. This is the period when settlements schemes were set up in the forested areas, which were in late 1980s and early 1990s as well as forest excisions in early 2000s.

There has been a significant increase in area under dense vegetation and decrease in farmlands in 2020 due to the efforts in place by various institutions to restore the catchment. Woodlands have slightly increased over the years by $6.7 \%$ with the greatest increase between 1979 and 1989, followed by a decline till 2009 and further increase in 2020 due to reforestation and natural restoration. The area under grasslands has continually remained low over the years. There has been an increase by $3.4 \%$ from 18019 Ha to 12726 Ha between 1979 and 2020. The area under forest cover has declined by $59661 \mathrm{Ha}$, which is a substantial loss given the importance of Eastern Mau Forest Reserve as a major water catchment forming the Mau Complex water tower.

Figure 2: Land use/cover spatial changes in Eastern Mau from 1979-2020

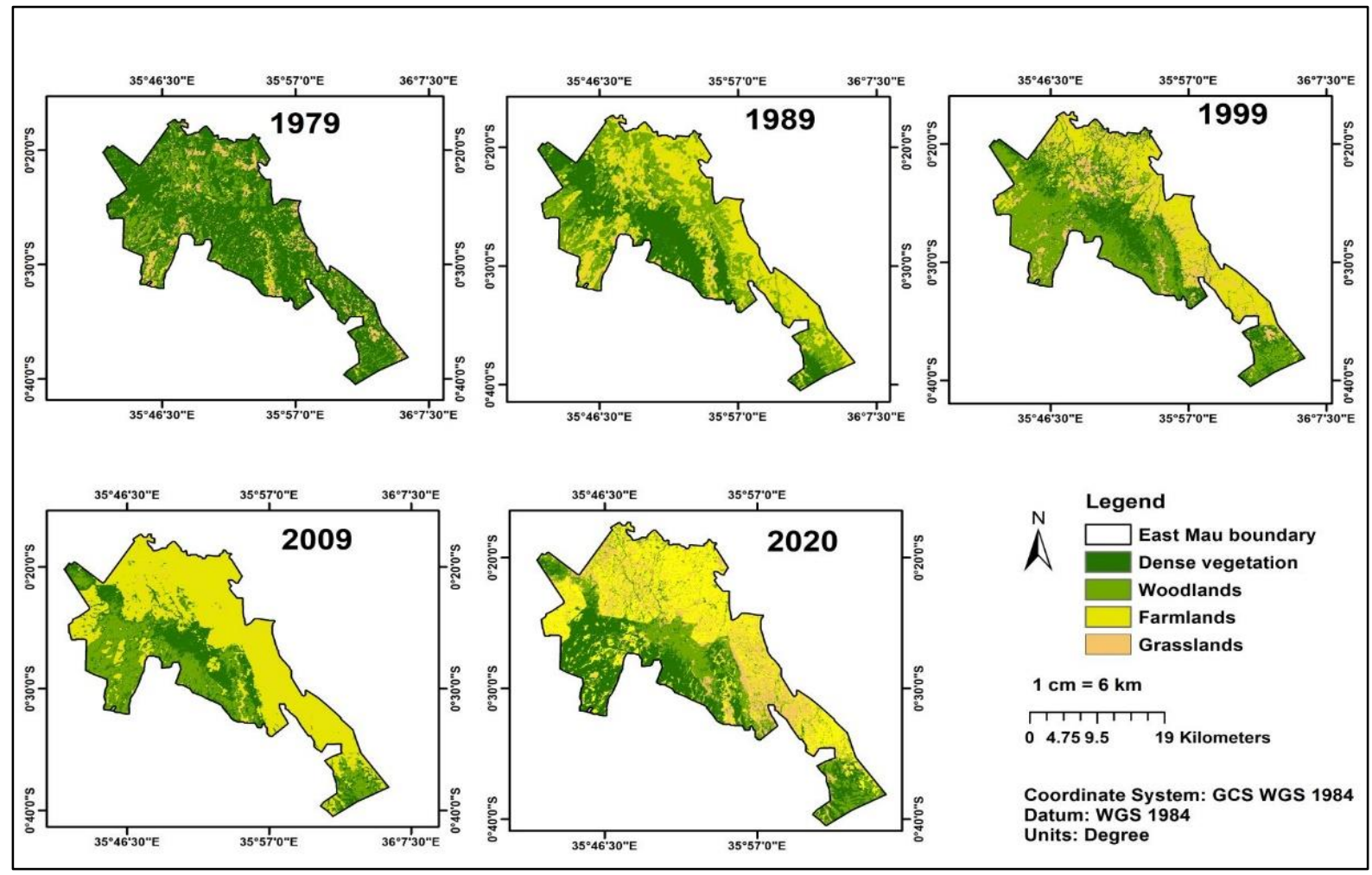

42 This work is licensed under a Creative Commons Attribution 4.0 International License. 
Figure 3 shows the fluctuations in land cover changes over time. Grasslands is the least fluctuating land cover. There is an inverse relationship between dense vegetation and farmlands since an increase in farmlands leads to a decrease in dense vegetation and vice versa. The woodlands have slight fluctuations over the years with a significant decline till 2009 and increase in 2020. The woodlands are found inside the forested areas or within settled areas whether planted or natural, but do not form canopies. In 2009, the area under farmlands was at its highest and dense vegetation was at its lowest. This changes after 2009 due to interventions aimed at restoring the reserve. The decade between 2010 and 2020 is characterised by a slight increase in dense vegetation cover and slight decline in woodlands and farmlands.

\section{Figure 3: Land use/cover trends in Eastern Mau from 1979-2020}

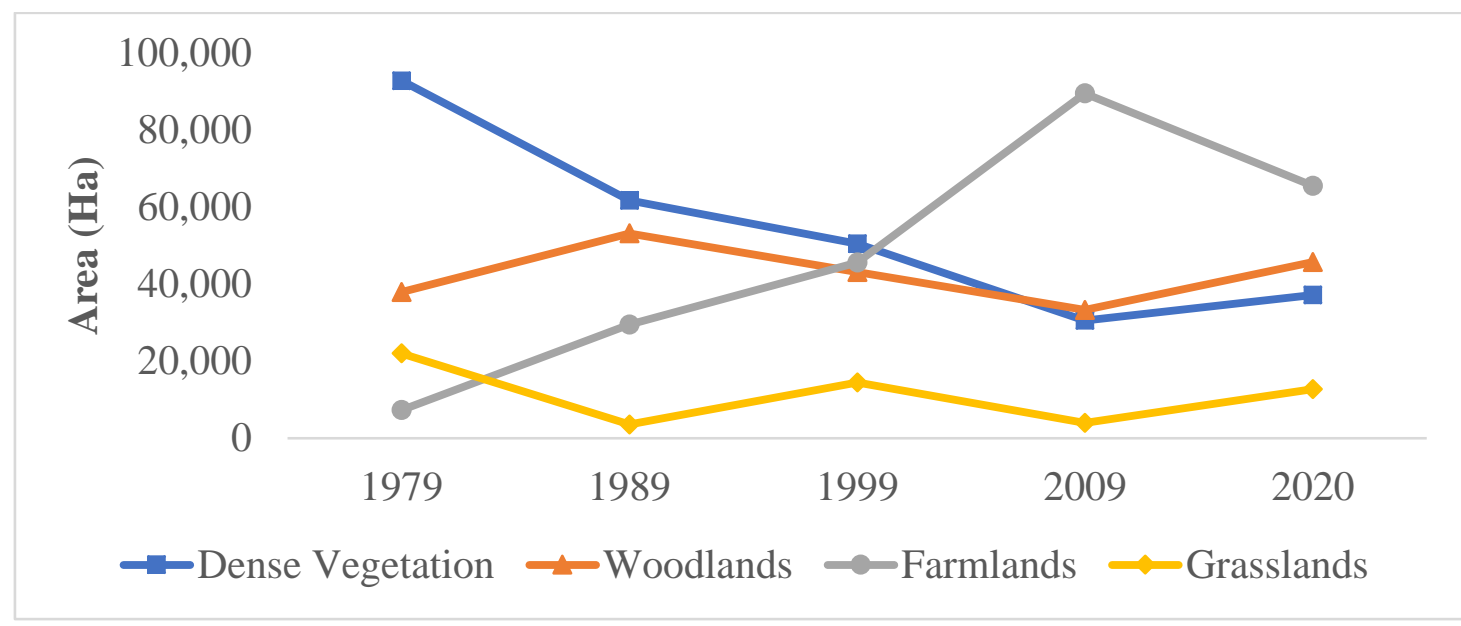

\section{Settlement Schemes in Eastern Mau Forest Reserve}

Settlement schemes in Eastern Mau began in the late 1980 s and early 1990 s as a political move to settle communities by the Kenya African National Union (KANU) regime. The result is massive destruction of the forests to pave way for settlements (Klopp, 2012). In 2001, over $200 \mathrm{~km}^{2}$ of the forest was excised by the government following a Gazette Notice No. 889 of 16th February 2001 (RoK, 2012). The lack of a buffer system to deter further encroachment has prompted people to extend farm boundaries, thus encroaching into forest reserve. These excisions have been the greatest threats to Eastern Mau as it opened up the forest to encroachment and degradation (Njuguna, Mbegera, \& Mbithi, 1999).

There are seven settlement schemes in Eastern Mau Forest block that were established irregularly namely Sururu, Likia, Teret, Nessuit, Elburgon, Mariashoni and Baraget. The plans for settlement schemes and excisions for Eastern Mau Forest Reserve made in 2001 are in existence. However, people in the schemes have encroached beyond the delineated boundaries (RoK, 2004a). The settlement schemes within the reserve did not follow procedures of altering forest boundaries before titles were given, hence they are considered as irregularly established as stated in the Forest Act Cap 385 (Boone, 2012). The Act was aimed at protecting the forests, but also provided for alteration of forest areas. Figure 4 shows the boundaries of settlement schemes in Eastern Mau Forest Reserve. The encroached area of 12,968 Ha was not within the boundaries of settlement schemes, but people have settled in them. The lack of clear boundaries when settlement schemes were established has led to encroachments (Njuguna et al., 1999). 
Figure 4: Settlement schemes in Eastern Mau Forest Reserve

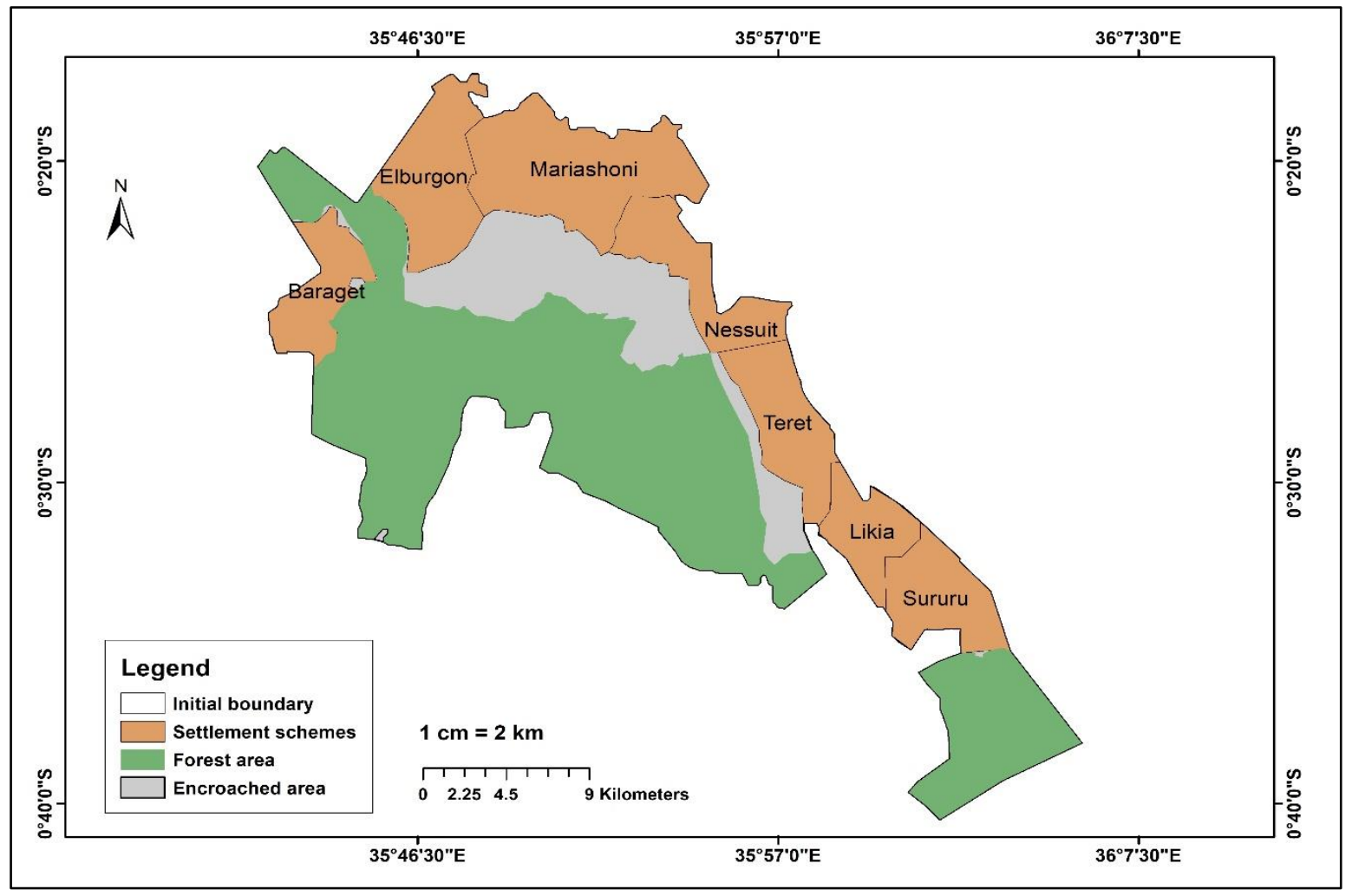

The non-procedural creation of settlement schemes led to the introduction of cutlines in Eastern Mau Forest reserve. There are various imaginary boundaries in the name of cutlines meant to suit varying interests of groups (Figure 5). The cutlines, however, present an informal situation, acting as a replacement of formal survey and demarcation of the forest boundary (RoK, 2004b). The creation of one official cutline is still under survey to determine current extent of the forest boundary. Figure 5 shows the boundaries of Eastern Mau Forest reserve over time. The proposed boundary follows the boundary of settlement schemes after Presidential directives and excisions. People who had encroached the forest are inside the proposed boundary and therefore likely to be displaced. The proposed boundary gets into some of the areas within the boundary after excisions. This is due to the fact that some areas are critical areas that need to be protected. The people within these affected areas will be allocated land elsewhere outside the forested area to avoid tensions among people already living within the existing boundaries.

The encroachments into the forested area started after 2001 and continued gradually till evictions of people started. The realization of the importance of Eastern Mau Forest reserve as a catchment and threats that it faces has led to efforts meant to restore it (KWTA, 2017). The first attempt at evictions were between 2004 and 2006 however they were not successful as people went back to the forest afterwards, due to inadequate measures that would deter them from heading back (RoK, 2009). Evictions similarly followed in 2009 and 2018 with more than 50,000 people evicted from their homes (Human Rights Watch, 2020). The refusal by some people to move out of Eastern Mau has led to use of force by the government in their evictions, leading to conflicts between people and the enforcing bodies. 
Figure 5: Boundary Cutlines of Eastern Mau Forest Reserve

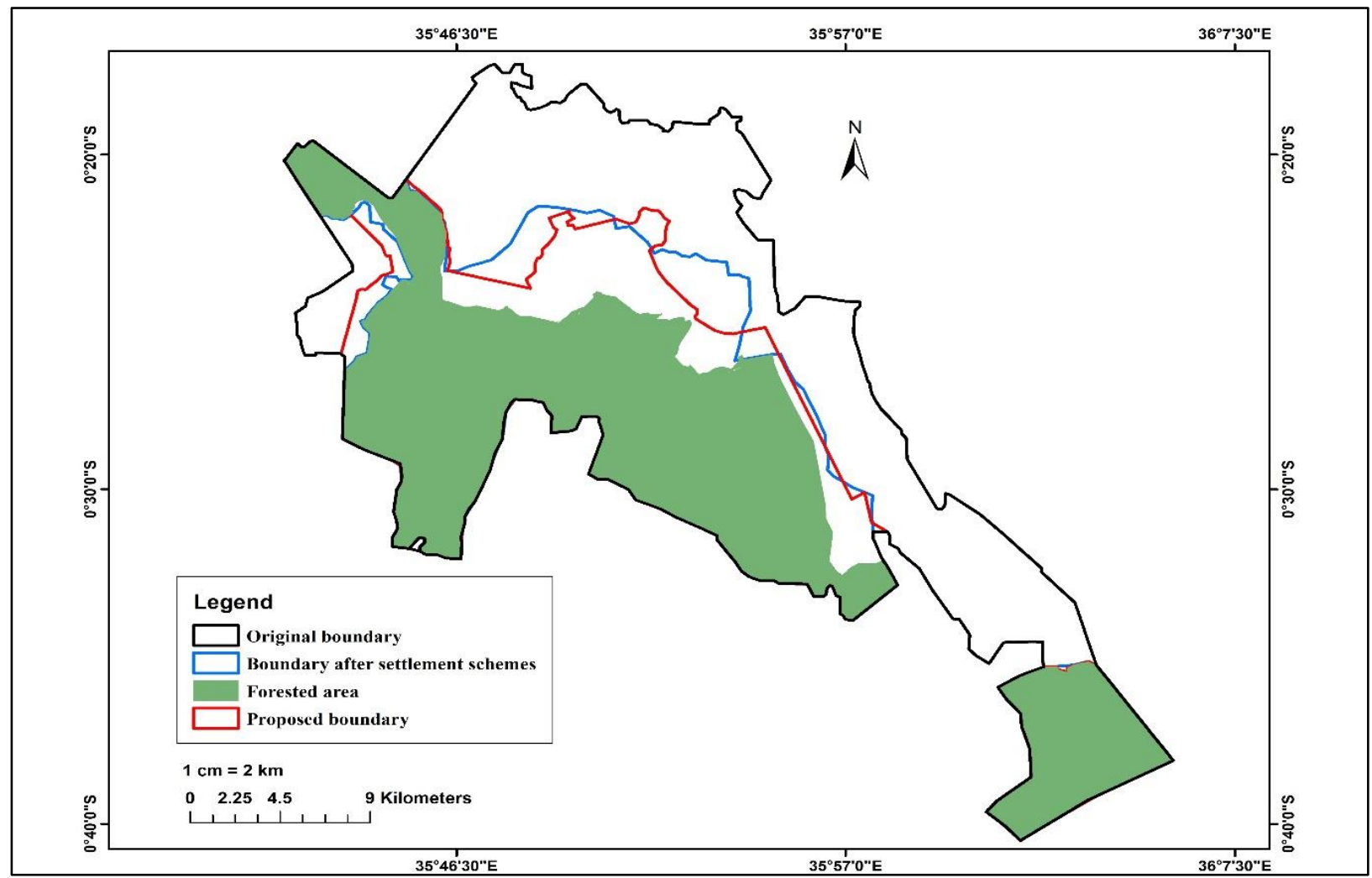

\section{Rainfall and River Flows in Eastern Mau}

To understand how human settlements have affected river flows, it is important to understand the condition of the rivers, streams and wetlands in Eastern Mau and the trends in rainfall over time. Eastern Mau Forest Reserve is a major water catchment owing to the many rivers, streams and wetlands that feed into water bodies as shown in Table 1 and Figure 6. River - Njoro, Nderit, Makalia and Naishi flow into Lake Nakuru, the home of flamingos whereas Molo River flow into Lake Baringo, another habitat of flamingos. The tributaries of the Mara River that drain into Lake Victoria also stem from Eastern Mau (KWTA, 2017). 
Figure 6: Farmlands and Rivers in Eastern Mau Forest Reserve

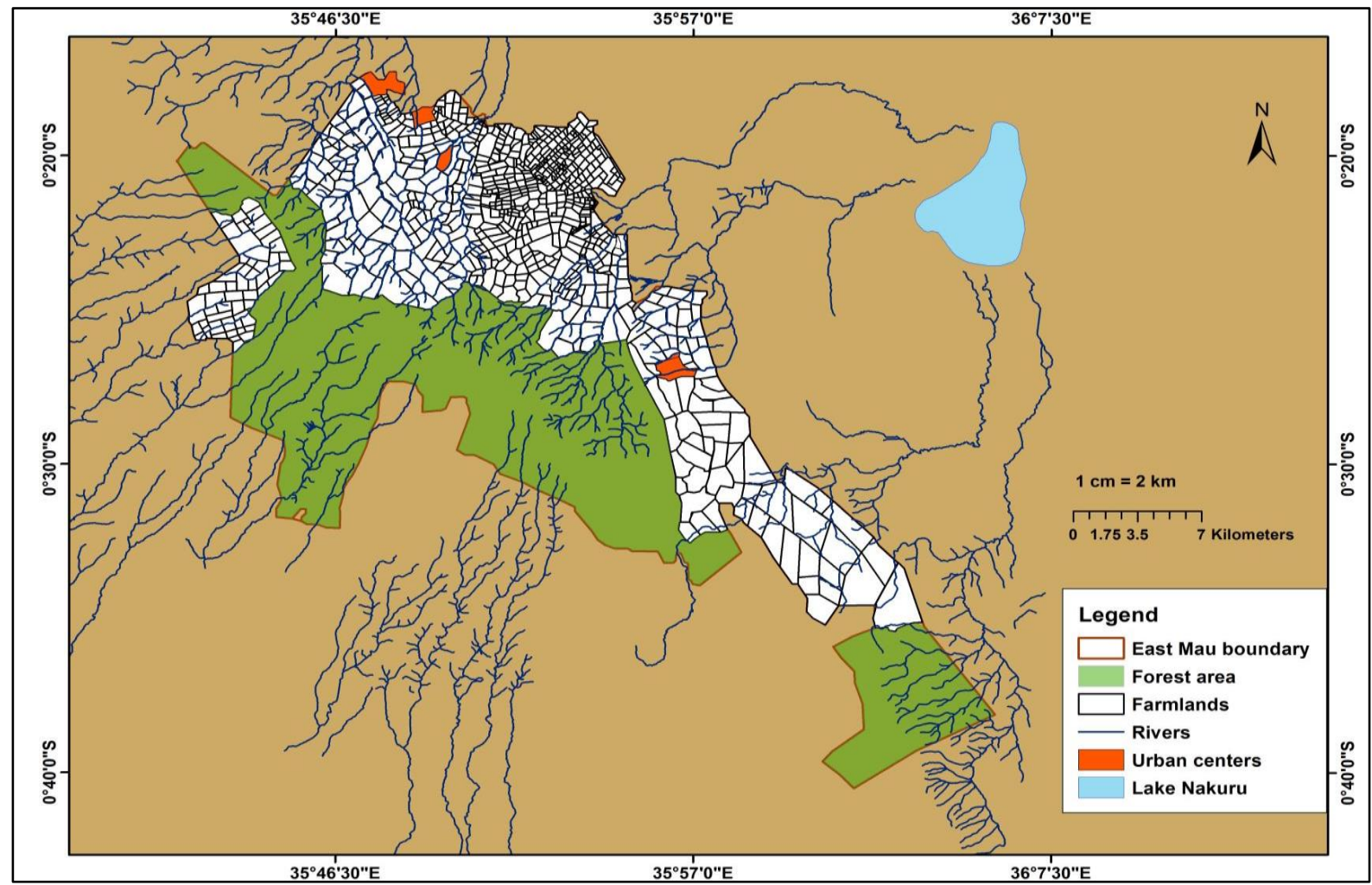

Figure 6 shows farmlands, rivers and tributaries within the forest reserve. Figure 6 indicates that some rivers and streams are emanating from the settlement (farmlands) areas, inside the current forested area and outside the former Eastern Mau Forest Reserve. During demarcation, no land was set aside for riparian zones and conservation of wetlands (Kweyu et al., 2019). Most tributaries are found within the forested area hence the need to preserve the riparian areas from further destruction.

The settlement of people within the forested areas have led to drying of rivers, streams and wetlands with other sources becoming seasonal (Table 1). In the Njoro area for instance, 13 streams out of 32 have dried up over the last 40 years including Mumberes whereas Larmudiak Rivers, Umani Spring and Napuiyapui swamp have turned seasonal. Table 1 shows some of the existing, seasonal and dried-up rivers and streams flowing from Eastern Mau. Most of the streams that have dried up are found outside what is currently the forested area (Nyawira, Mwangi, \& Cheruiyot, 2019). As people continue to settle and farm upstream near the forested area, the downstream areas are affected immensely due to siltation, which compromises river flows. Human settlements have therefore affected river flows.

Table 1: Existing and dried-up rivers and streams in Eastern Mau

\begin{tabular}{lllllll}
\hline Rivers & & Streams & & & \multicolumn{2}{l}{ Wetlands } \\
\hline Existing & Dried up & Existing & & Dried up & Existing & Seasonal \\
\hline Njoro & Mumberes & Elburgon & Rongai & Isirkon, Enchorro, & Maji- moto & Napuiyapui \\
Molo & & Enkare & & Kaplekwa, Munji, Nguso & swamp \\
Naishi & & Mau & Kiptunga, & Chepkutbei, Sugutek, & & Umani \\
Makalia & & Nessuit, & Ndarugu, & Kiboso Lelechwet, & Larmudiak \\
Enderit & & Shuru, & Ngosur, & Chepkitach, & & \\
\hline
\end{tabular}

46 This work is licensed under a Creative Commons Attribution 4.0 International License. 


\begin{tabular}{|c|c|c|c|c|c|c|}
\hline \multirow{2}{*}{$\begin{array}{l}\text { Rivers } \\
\text { Existing }\end{array}$} & \multicolumn{3}{|c|}{ Streams } & \multicolumn{3}{|c|}{ Wetlands } \\
\hline & Dried up & Existing & & Dried up & Existing & Seasonal \\
\hline & & $\begin{array}{l}\text { Kibunja, } \\
\text { Langs, } \\
\text { Kisonei, } \\
\text { Olorropi, } \\
\text { mbili, } \\
\text { Kipsinende }\end{array}$ & $\begin{array}{l}\text { Waiseges, } \\
\text { Kihingo, } \\
\text { Entiyani, } \\
\text { Daraja- } \\
\text { Tuiyopei, }\end{array}$ & $\begin{array}{l}\text { Kapseita, } \\
\text { Chepakundi, } \\
\text { Lengape, }\end{array}$ & & \\
\hline
\end{tabular}

(Adapted from KWTA, 2017)

Settlement of people in the forest reserve was based on the Forest Act which aimed at reservation, protection and control of forests by the government (RoK, 1982). The presence of human activities within the forest reserve threatens the existence of streams and rivers (Kibuba \& Jenkins, 2005). Humans rely on rivers for different resources; however, the lack of conservation programs and awareness greatly affect the reserve (Anthony, 2018). The area under forest cover has decreased immensely and as people head towards the higher points, destruction of tributaries is imminent without conservation programs. The lack of proper enforcement of the law and forest management regulations in the area encourages further deforestation and degradation of the reserve (RoK, 2018).

The mean annual rainfall and river flows from Figure 7 indicate that there have been significant changes in the rainfall and river flow in River Njoro. The highest rainfall amounts are recorded in 2020 at $2100 \mathrm{~mm}$ and 1980 has the lowest at $900 \mathrm{~mm}$. The river flows in 2020 show a gradual decline and the flows between 1979 and 1980 also indicate a decline in river flows followed by a significant rise in the flows. 2011 recorded the highest river flow amounts at $0.83 \mathrm{~m}^{3} / \mathrm{s}$ and 1986 recorded the lowest annual flow of $0.1 \mathrm{~m}^{3} / \mathrm{s}$. 2011 also recorded the second highest rainfall levels at $1940 \mathrm{~mm}$ after 2020. In 1986, the rainfall levels are slightly at a lower level at $1000 \mathrm{~mm}$.

There has been consistent change in the river flows between 1979 and 2001. Between 1979 and 2001, there has been consistent increase and decrease in river flows over a certain period, with similar trends in rainfall levels. This is marked by a gradual increase from 2001 to 2011 with peak flows in 2011. There is a general decline in river flows from 2011 to 2016 with an upward trend recorded from 2017 to the highest in 2020. The rainfall levels increase from 2001 to 2005 then declined until 2009. The rainfall levels increase till 2011, decline till 2015 and have been increasing till its peak in 2020 .

Figure 7: Annual rainfall and river flows in River Njoro

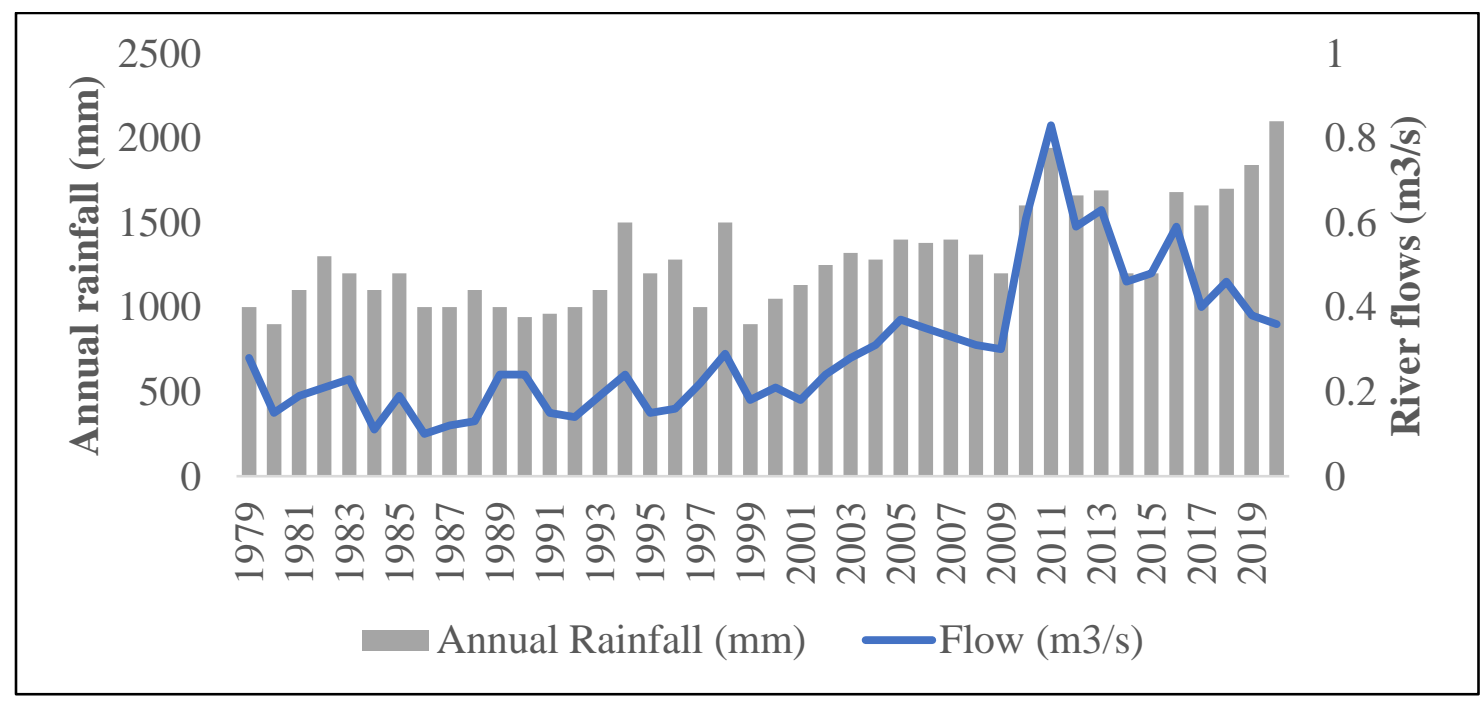

47 | This work is licensed under a Creative Commons Attribution 4.0 International License. 
The annual rainfall between 1979 and 1998 recorded a consistent increase then decline in rainfall amounts over the years. The river flows during the same period recorded a swing that is defiant of rainfall patterns. Between 1979 and 2009, the river flows are at lower levels in comparison to rainfall levels, with rainfall and river flows being in a direct proportion in most years until 1999. Between 2010 and 2017, the flows rise to higher levels compared to previous years and afterwards there is a declining trend.

Figure 8 shows the mean monthly river flows from 1979 to 2020. In Eastern Mau, the long rains are from March to May with short rains between July and September. There is a gradual increase in river flows during the long rains from 1979 to 2020 with an exception of 1999. 2020 recorded the highest river flows in April with the lowest in 1999. There is a gradual decline in flows during the short rains from 1979 to 2009 with 2020 recording the highest and 2009 the lowest in the month of September. There are changes in river flows during the long and shorts rain. The shift in river flows over the different months is attributed to the decrease in short rains and increase in long rains due to deforestation in the area. The river flows have increased during the long rains and decreased during the short rains. The monthly river flows have fluctuated the most during the peak and low rainfall seasons.

Figure 8: Monthly river flows of River Njoro

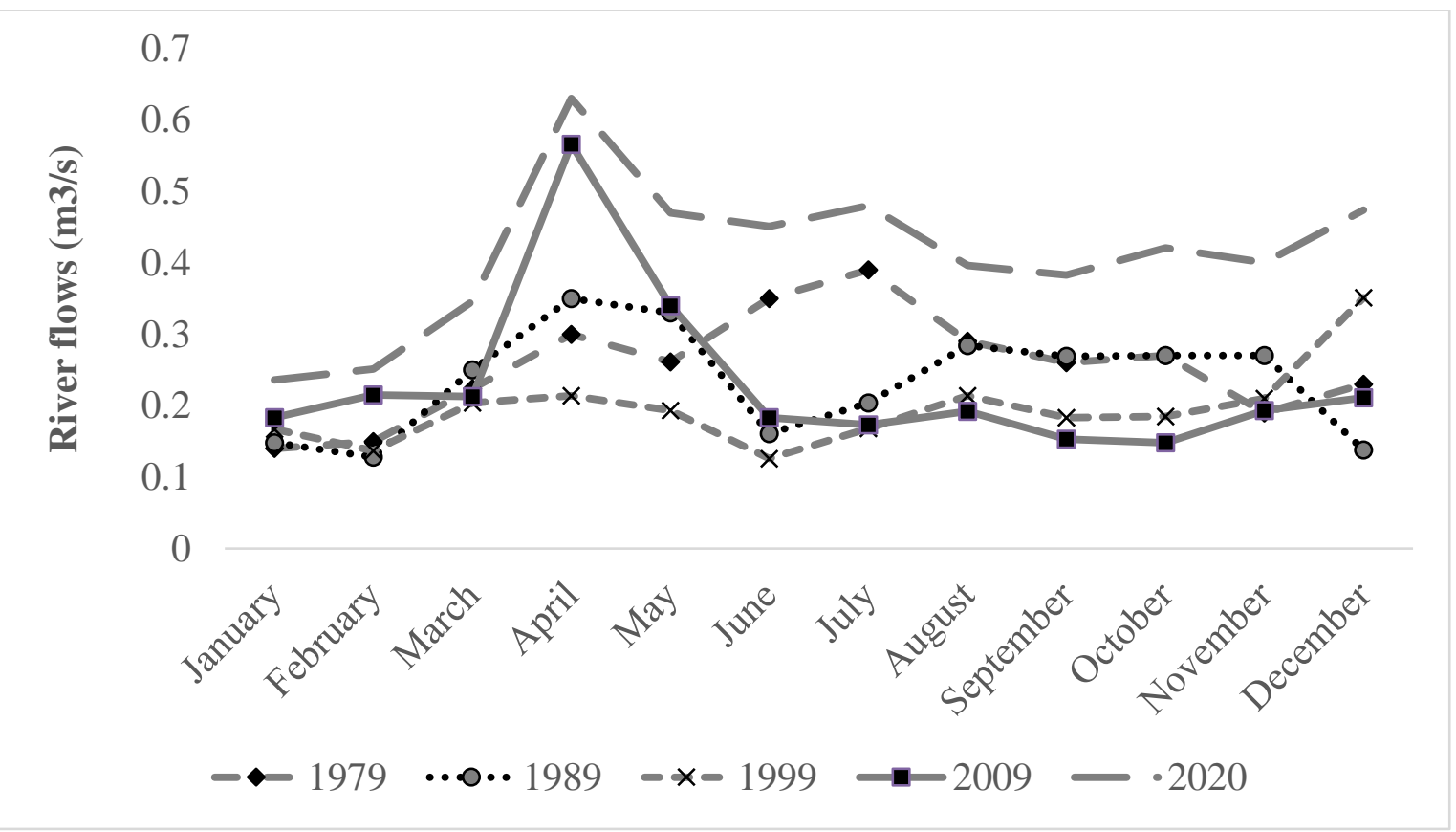

\section{Impact of Human Settlements on River Flows}

Monthly river flows are affected by the kind of anthropogenic activities taking place around a stream. Land preparation for planting in the forest reserve mostly takes place in January and February when the rainfall levels are low. As the rains set in and planting begins, the soil is bare, with less vegetation growing. Harvesting takes place during the low rainfall seasons. Figure 9 shows the correlation between area under farmlands and river flows. There is a positive correlation between farmlands and river flow data between 1989 and 2020. An increase in farmlands leads to an increase in river flows. There is a negative correlation in 1979 since there was minimal farming areas in the forest reserve. 
Figure 9: Correlation between farmlands and river flows in Eastern Mau

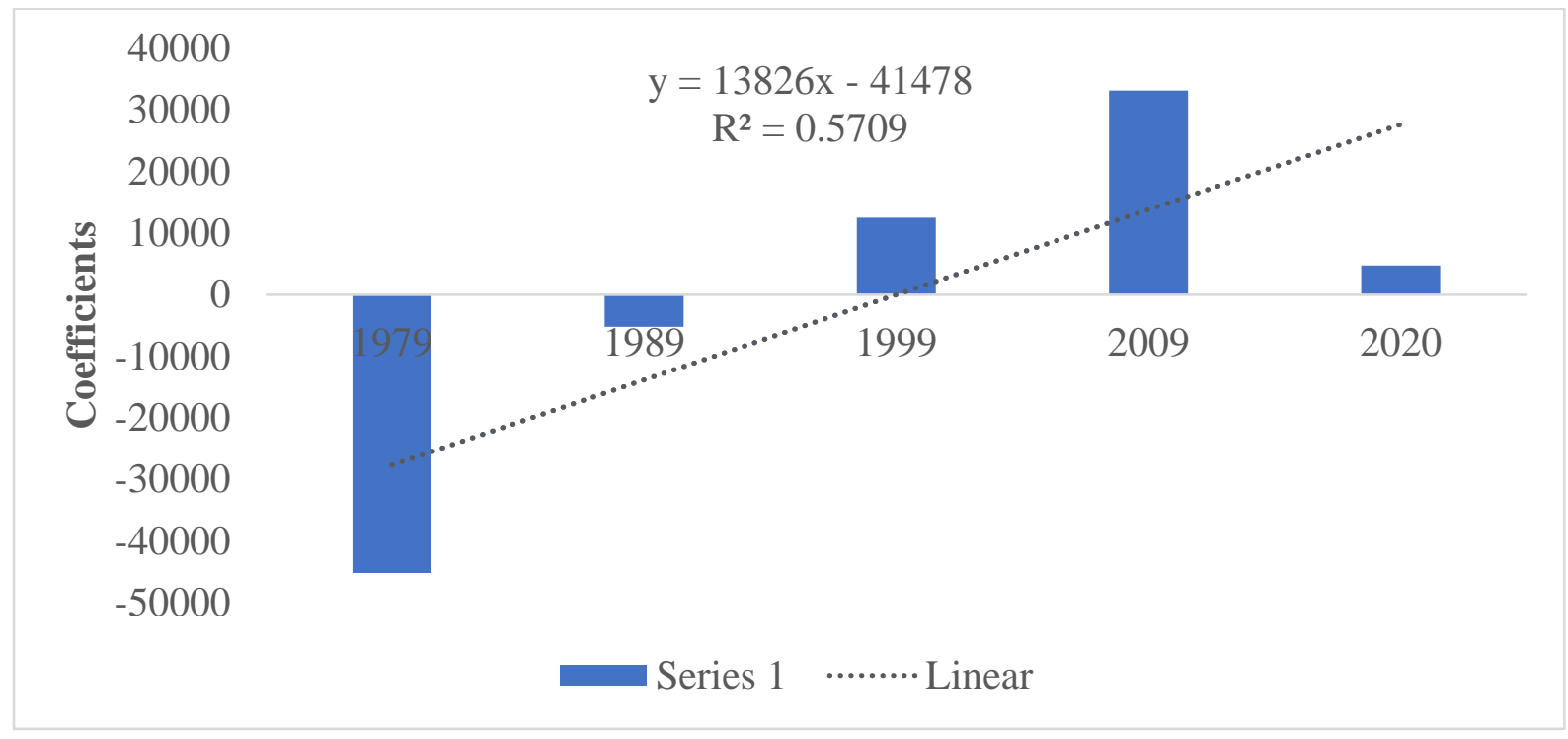

There have been substantial changes in river flows over the years. The increase in river flows is an indication of increase in surface run-off from each rainfall event in the area. Increase in surface run-off results from less infiltration and interception of water from decrease in forest cover, tree plantations and increase in farmlands. The decrease in forest cover leads to an increase in total volume of flow due to reduction in evapotranspiration and decreased interception of rainfall (Mainuri, 2018). As more people continue to settle in the forest area, they engage in activities which support their livelihoods like agriculture. The continuous ripping of vegetated areas leaves the land bare and without vegetation to hold soil in place. The result is increased surface run-off hence sedimentation in the rivers.

The results are similar to those obtained by Xie, Bie and $\mathrm{He}$ (2017), where they noted a decline in monthly river flows over the years that was attributed to deforestation and increased water use as a result of human settlements. The decrease in vegetation cover leads to increase in annual discharges and surface run-off. There is also less infiltration of water which is responsible for revitalizing the streams. The high peaks will only last when there are high rainfall levels and as the rainfall levels decrease, flows decrease even in springs. The alteration of water bodies at the upstream level affects the whole catchment system (Masuma \& Adullah, 2020). This indicates that the reserve has experienced changes which have greatly affected river flows.

\section{CONCLUSION}

Eastern Mau Forest Reserve is a catchment that a number of rivers, streams and wetlands emanate from inside the forested area, in the established settlement schemes and outside the forest reserve. Settlement schemes have led to land use changes in Eastern Mau as a result of conversion from forest to farmlands. There is an inverse proportion between farmlands and forests where a decrease in forests leads to an increase in farmlands. There is a relationship between river flows and farmlands as an increase in area under farmlands leads to an increase in river flows. Settlements affect land cover, which in turn affects forests and impacts capacity of land to absorb rainfall water, which leads to higher runoff and subsequently higher flows. The study therefore recommends that permanent riparian zones be established within the forest reserve to prevent further encroachments. The government also needs to come up with practical strategies and plans to get people out of the forest and ensure their safe transition to other places. 


\section{REFERENCES}

Alamgir, M., Campbell, M. J., Sloan, S., Engert, J., Word, J., \& Laurance, W. F. (2020). Emerging challenges for sustainable development and forest conservation in Sarawak, Borneo. PloS one, 15(3), e0229614.

Boone, C. (2012). Land conflict and distributive politics in Kenya. African Studies Review, 55(1), 75-103.

Chaudhry, S. (2019). Politics of land excisions and climate change in the Mau Forest Complex: A case study of the South-Western Mau Forest. Journal of Sustainability, Environment and Peace, 1(2), 52-62.

FAO. (2017). Watershed management in action: Lessons learned from FAO field projects. New York: Food and Agriculture Organization.

Gills, B., \& Morgan, J. (2020). Global climate emergency: After COP24, climate science, urgency, and the threat to humanity.

Guzha, A. C., Rufino, M. C., Okoth, S., Jacobs, S., \& Nóbrega, R. L. B. (2018). Impacts of land use and land cover change on surface runoff, discharge and low flows: Evidence from East Africa. Journal of Hydrology: Regional Studies, 15, 49-67.

Human Rights Watch (2020). Kenya: Mau Forest Evictees' Plight Intensifies.

Jorge, M. G., \& Julio, J. D. (2012). Sustainable Forest Management: An Introduction and Overview: InTech.

Kibuba, F., \& Jenkins, M. (2005). Managing the River Njoro Watershed, Kenya: Conflicting laws, policies, and Community Priorities.

Kimaru, A. N., Gathenya, J. M., \& Cheruiyot, C. K. (2019). The temporal variability of rainfall and streamflow into lake Nakuru, Kenya, assessed using SWAT and hydrometeorological indices. Hydrology, 6(4), 88.

Klopp, J. (2012). Deforestation and Democratization: Patronage, Politics and Forests in Kenya. Journal of Eastern African Studies, 6(2), 351-370.

Kweyu, R., Kiemo, K., Thenya, T., Emborg, J., \& Gamborg, C. (2019). Spatial and Political Factors in Forest Resource Conflicts: The Eastern Mau Forest Case 1992-2014. Society \& Natural Resources, 32(11), 1276-1292.

KWTA (2017). Kenya Water Towers Status Report. Nairobi: Kenya Water Towers Agency.

Lopez, D., \& Jason, B. (2013). Deforestation Drivers: Population, Migration and Tropical Land Use. Environment, 55(1), 1-18.

Mainuri, Z. G. (2018). Impact of Human Settlement on Land Use/Land Cover Changes in the Middle River Njoro Sub Watershed in Kenya. European Journal of Multidisciplinary Studies, 3(4), 180188.

Masuma, C., \& Adullah, A.-M. (2020). Land Use/ Land Cover Change Assessment of Halda Watershed Using Remote Sensing and GIS. The Egyptian Journal of Remote Sensing and Space Sciences, 23(1), 63-75.

Ndubi, A. O. (2018). Using land cover change to predict forest degradation pressure points, Eastern Mau Forest, Kenya. International Letters of Natural Sciences, 71.

Njuguna, P., Mbegera, M., \& Mbithi, D. (1999). Reconaisance Survey of Forest Blocks in the West and East of the Rift Valley.

Olang, L. O., \& Kundu, P. M. (2011). Land degradation of the Mau forest complex in Eastern Africa: a review for management and restoration planning (Vol. 528). In-Tech.

Prăvălie, R. (2018). Major perturbations in the Earth's forest ecosystems. Possible implications for global warming. Earth-Science Reviews, $185,544-571$

RoK (2004a). Report of the Commission of Inquiry into the Illegal/Irregular Allocation of Public Land: Annexe Volume II. 
RoK (2004b). Report of the Commission of Inquiry into the Illegal/Irregular Allocation of Public Land: Annexes Volume I.

RoK (2012). Kenya Gazette No. 27. (2012). Nairobi

RoK (2018). A Report on Forest Resources Management and Logging Activities in Kenya.

Sauer, S. (2018). Soy expansion into the agricultural frontiers of the Brazilian Amazon: The agribusiness economy and its social and environmental conflicts. Land Use Policy, 79, 326-338.

UNESCO (2014). International Hydrological Programme VIII: Water Security Responses to Local, Regional and Global Challenges. Paris, France: UNESCO Division of Water Sciences.

Xie, Y., Bie, Q., \& He, C. (2017). Human settlement and changes in the distribution of river systems in the Minqin Basin over the past 2000 years in Northwest China. Ecosystem Health and Sustainability, 3(11), 1401011.

Yang, S., Zhao, W., Liu, Y., Wang, S., Wang, J., \& Zhai, R. (2018). Influence of land use change on the ecosystem service trade-offs in the ecological restoration area: Dynamics and scenarios in the Yanhe watershed, China. Science of the total environment, 644, 556-566.

51 | This work is licensed under a Creative Commons Attribution 4.0 International License. 